\title{
PENGARUH MODEL PEMBELAJARAN CLIS BERBANTUAN MEDIA LINGKUNGAN TERHADAP KOMPETENSI PENGETAHUAN IPA
}

\author{
I Wayan Suadnyana Putra', DB. Kt. Ngr. Semara Putra ${ }^{2}$, Ni Nyoman Ganing ${ }^{3}$ \\ 1,2,3 Jurusan Pendidikan Dasar, Universitas Pendidikan Ganesha, Indonesia \\ e-mail: wayan.suadnyana.putra@undiksha.ac.id, semara.putra@undiksha.ac.id , \\ ninyoman.ganing@undiksha.ac.id
}

\begin{abstract}
ABSTRAK
Penelitian ini bertujuan untuk mengetahui perbedaan yang signifikan kompetensi pengetahuan IPA kelompok siswa yang dibelajarkan menggunakan model pembelajaran Children's Learning In Sciense (CLIS) berbantuan media lingkungan dan kelompok siswa yang dibelajarkan menggunakan pembelajaran konvensional siswa kelas IV SD Negeri Gugus Kolonel I Gusti Ngurah Rai Denpasar Utara 2018/2019. Penelitian ini merupakan penelitian eksperimen semu dengan rancangan kelompok non-ekuivalen. Populasi pada penelitian ini ialah seluruh siswa kelas IV SD Negeri Gugus Kolonel I Gusti Ngurah Rai Denpasar Utara 2018/2019 yang berjumlah 464 siswa. Penentuan sampel dalam penelitian menggunakan teknik random sampling dengan pengacakan kelas yang sudah ada, kemudian dilakukan pengudian untuk penentuan kelompok eksperimen dan kontrol sehingga kelas IVB SD Negeri 4 Ubung yang berjumlah 40 siswa sebagai kelompok eksperimen dan kelas IVB SD Negeri 5 Ubung yang berjumlah 35 siswa sebagai kelompok kontrol. Data kompetensi pengetahuan IPA siswa dikumpulkan dengan instrumen tes objektif pilihan ganda biasa sebanyak 25 soal yang sudah divalidasi. Nilai gain score dinormalisasi dianalisis menggunakan uji-t. Hasil analisis uji-t menunjukkan nilai $\mathrm{t}_{\text {hitung }}=2,558>\mathrm{t}_{\text {tabel }}(\mathrm{a}=0,05, \mathrm{dk}=73)=2,000$ sehingga $\mathrm{H} 0$ ditolak dan Ha diterima. Sesuai dengan hasil tersebut dapat disimpulkan terdapat pengaruh yang signifikan kompetensi pengetahuan IPA kelompok siswa yang dibelajarakan menggunakan model pembelajaran CLIS berbantuan media lingkungan dan kelompok siswa yang dibelajarakan menggunakan pembelajaran konvensional siswa kelas IV SD Negeri Gugus Kolonel I Gusti Ngurah Rai Denpasar Utara 2018/2019. Untuk peneliti yang memiliki kesamaan variabel, hasil penelitian ini dapat dipergunakan sebagai kajian penelitian relevan.
\end{abstract}

Kata Kunci : CLIS,lingkungan, IPA

\begin{abstract}
This research aims to know the significant difference of science competency between students taught by learning model Children's Learning in Sciencewith Enviromet Media and students taught by conventional technique at 4 grades students of SD N Gugus Kolonel I Gusti Ngurah Rai Denpasar Utara year 2018/2019. This is a quasi-experimental research with non-equivalent control group design. The population was all 4 grades students at SD N Gugus Kolonel I Gusti Ngurah Rai Denpasar Utara which consist of 464 students. In deciding the sample, random sampling technique was used after randomized the class and using lottery to choose the experimental and control group. IVB class of SD N 4 Ubung which consist of 40 students was chosen as experimental group and IVB class of SD N 5 Ubung which consist of 35 students as control group. The data was collected using common multiple choices, consist of 25 items, which already valid. The score was analyzed using ttest. The result shows that the score of $t_{\text {calculated }}=2,558>t_{\text {table }}(a=0,05, d k=73)=2,000$ causing $H_{0}$ is rejected and $H_{A}$ is accepted. From that result, it is concluded that there is a significant difference of science competency between students taught by CLIS with environment media and students taught conventionally on 4 grades students at SD N Gugus Kolonel I Gusti Ngurah Rai Denpasar Utara 2018/2019. For other researchers who have the same variable, this can be a relevant reference.
\end{abstract}

Keywords : CLIS, Environment, Science 


\section{Pendahuluan}

Pendidikan memegang peranan penting dalam mempersiapkan sumber daya manusia yang berkualitas dan mampu berkompetisi dalam perkembangan ilmu pengetahuan dan teknologi, sehingga pendidikan harus dilaksanakan dengan sebaikbaiknya untuk memperoleh prestasi belajar yang maksimal. Hal tersebut dapat dicapai dengan terlaksananya pendidikan yang tepat waktu dan tepat guna untuk mencapai tujuanp pembelajaran. Pembelajaran matematika di sekolah merupakan salah satu komponen pendidikan yang tidak hanya mengembangkan kemampuan dan keterampilan menerapkan matematika, melainkan mengembangkan kemampuan memecahkan masalah (Wijayanti, 2014).

Pendidikan merupakan salah satu cara yang ditempuh untuk membangun masyarakat yang cerdas, damai, terbuka dan demokratis. Seperti yang tercantum dalam pasal 1 ayat 1 UU No. 20 Tahun 2003 tentang sistem Pendidikan Nasional menyebutkan bahwa : Pendidikan merupakan usaha sadar dan terencana untuk mewujudkan suasana belajar dan proses pembelajaran agar peserta didik aktif mengembangkan potensi dirinya untuk memiliki untuk memiliki kekuatan spiritual keagamaan, pengendalian diri, kepribadian kecerdasan, akhlak mulia serta keterampilan yang diperlukan dirinya, masyarakat, bangsa dan Negara. Salah satu upaya yang ditempuh oleh pemerintah untuk memperbaiki kualitas mutu pendidikan yaitu melalui pengembangan kurikulum. Kurikulum yang diterapkan saat ini di Indonesia adalah kurikulum 2013. Pada hakikatnya pengembangan kurikulum 2013 merupakan upaya yang dilakukan melalui salah satu elemen pendidikan, yaitu kurikulum untuk memperbaiki kualitas hidup dan kondisi sosial bangsa Indonesia secara lebih luas.

Kurikulum 2013 mulai diimplementasikan di sekolah secara luas pada tahun ajaran 2014. Kesiapan guru dalam melaksanakan pembelajaran lebih dimudahkan dengan ketersediaan buku siswa dan buku guru sebagai sumber belajar utama sehingga diharapkan pembelajaran akan lebih efektif. Buku guru merupakan sumber belajar utama yang berisi materi dan skenario pembelajaran sehingga guru harus menggunakan buku ini sedangkan sumber belajar lain sifatnya suplemen. Kreativitas siswa menjadi aspek penting yang harus dipertimbangkan ketika guru merancang pembelajaran. Guru yang kreatif dan mampu menyajikan materi pembelajaran dengan pendekatan saintifik yang akan mampu memfasilitasi siswa menjadi kreatif (Kemendikbud, 2013). Apabila mengkaji arah pengembangan kurikulum 2013, maka perguruan tinggi yang mencetak calon guru juga harus menyesuaikan dengan tuntutan dan kebutuhan sekolah. Mahasiswa calon guru, sejak menempuh perkuliahan perlu difasilitasi agar memiliki kreativitas terutama pada mata kuliah yang memberikan bekal pada penyusunan perangkat pembelajaran (Khusniati, 2014).

Penerapan Kurikulum 2013 ini dapat dikembangkan pada seluruh materi yang terintegrasi dalam tema pokok, guna membentuk karakter siswa yang tidak hanya cerdas dalam pengetahuan namun juga terampil dan bijak dalam mengembangkan sikap yang baik proses sikap dan juga pengetahuan, salah satu materi yang mengedepankan sikap dan pengetahuan yaitu materi IImu Pengetahuan Alam (IPA). Wisudawati dan Sulistyowati (2015:22) mengemukakan bahwa, "IPA merupakan rumpun ilmu, memiliki karakteristik khusus yaitu mempelajari fenomena alam yang factual (factual), baik berupa kenyataan (reality) atau kejadian (evens) dan hubungan sebab-akibatnya". Proses pembelajaran IPA diharuskan dapat menyajikan materi pembelajaran yang relevan dan dapat mendorong siswa untuk memunculkan alternatif pemecahan masalah.

Berdasarkan hasil observasi dan wawancara yang dilakukan pada tanggal 10 Desember 2018 dengan guru wali kelas IV dan beberapa siswa di masing-masing SD Negeri Gugus Kolonel I Gusti Ngurah Rai Kecamatan Denpasar Utara, dalam proses pembelajaran yang berkaitan dengan materi pembelajaran IPA diperoleh beberapa permasalahan yang terletak pada kegiatan pembelajaran di kelas lebih banyak berupa kegiatan menghafal sehingga siswa mengalami mengalami kesulitan dalam memahami konsep. Siswa juga mengalami kesulitan dalam mengontruksi pengetahuannya karena kegiatan pembelajaran yang memerlukan aktivitas siswa untuk terlibat secara aktif masih terbatas. Selain itu, dalam penggunaan model pembelajaran masih monoton dan penggunaan media dalam proses 
pembelajaran yang masih jarang, Kondisi yang seperti ini tentunya akan memberi dampak yang kurang baik pada kompetensi pengetahuan yang dicapai oleh siswa.

Dari beberapa permasalahan yang telah dipaparkan, dengan menerapkan model pembelajaran yang inovatif yang dapat melibatkan peran siswa secara aktif dalam kegiatan pembelajaran akan memberikan pengaruh positif dalam pembelajaran IPA. Salah satu model pembelajaran yang cocok diterapkan dalam pembelajaran IPA adalah model pembelajaran children learning in sciense yang disingkat menjadi CLIS. Ambarwati (2016) menyatakan, model pembelajaran CLIS merupakan model pembelajaran yang menuntut siswa untuk terlibat langsung dalam berbagai aktivitas belajar, sehingga siswa tidak hanya menjadi objek pembelajaran, tetapi juga menjadi subjek pembelajaran yang dapat mengalami, menemukan, mengonstruksikan, dan memahami konsep. Salah satu cara menerapkan model pembelajaran yang inovatif yaitu dengan memanfaatkan alam sekitar dalam belajar, melibatkan siswa secara langsung dalam proses pembelajaran di dalam kelas maupun luar kelas serta membimbing siswa menemukan dan merekonstruksikan pengetahuannya sendiri. "Lingkungan merupakan sumber belajar yang paling efektif dan efesien serta tidak membutuhkan banyak biaya yang besar dalam meningkatkan motivasi belajar peserta didik" (Uno dan Nurdin, 2017:137). Model pembelajaran CLIS yang dikembangkan melalui bantuan media lingkungan akan mampu membawa pembaruan dalam pembelajaran. Kompetensi merupakan salah satu aspek dalam dunia pendidikan. "Dalam konteks pengembangan kurikulum, kompetensi merupakan perpaduan dari pengetahuan, keterampilan, nilai dan sikap yang direfleksikan dalam kebiasaan berpikir dan bertindak." (Sanjaya, 2016:70). Kompetensi merupakan perpaduan antara skill, tingkah laku dan pengetahuan serta nilainilai dasar yang dapat didemonstrasikan atau direfleksikan dalam kebiasaan dan kemampuan berpikir dan bertindak siswa yang dicapai melalui kegiatan mengajar (Yusuf, 2015). Kompetensi yang harus dikuasai oleh peserta didik perlu dinyatakan sedemikian rupa agar dapat dinilai, sebagai wujud kompetensi pengetahuan peserta didik yang mengacu pada pengalaman langsung. Pengetahuan adalah segala sesuatu yang diketahui manusia (Wisudawati dan Sulistyowati, (2014). Sani (2014:47) menyatakan "Dimensi pengetahuan yang harus dimiliki oleh siswa SD hanya merupakan pengetahuan faktual dan pengetahuan konseptual.Dimensi pengetahuan (dimensi proses kognitif) faktual dan konseptual terdiri dari mengingat, memahami dan mengaplikasikan". Sehingga dapat disimpulkan bahwa kompetensi pengetahuan merupakan perpaduan antara banyak aspek/ranah yang dapat dicapai siswa melalui kegiatan pembelajaran sehingga melalui kompetensi ini seseorang dapat menyelesaikan tugas dalam kegiatan pembelajaran. IPA merupakan salah satu mata pelajaran pokok dalam kurikulum pendidikan di Indonesia, termasuk jenjang SD. Susanto (2016:167) menyatakan bahwa "Sains atau IPA adalah usaha manusia dalam memahami alam semesta melalui pengamatan yang tepat pada sasaran, serta menggunakan prosedur, dan dijelaskan dengan penalaran sehingga mendapatkan suatu kesimpulan". IPA membahas tentang gejala-gejala alam yang disusun secara sistematis yang didasarkan pada hasil percobaan dan pengamatan yang dilakukan oleh manusia. Wisudawati dan Sulistyowati (2015:22) mengemukakan bahwa, "IPA merupakan rumpun ilmu, memiliki karakteristik khusus yaitu mempelajari fenomena alam yang factual (factual), baik berupa kenyataan (reality) atau kejadian (evens) dan hubungan sebab akibat". Sehingga dapat disimpulkan bahwa, IPA merupakan ilmu pengetahuan yang mempelajari peristiwa atau gejala alam yang berupa fakta-fakta, konsep-konsep, atau prinsip-prinsip yang merupakan hasil dari percobaan atau pengamatan dan disusun secara sistematis sehingga mendapatkan suatu kesimpulan.

Hakikat pembelajaran IPA dapat diklasifikasikan menjadi 3 bagian, Susanto (2016) menyebutkan bahwa, ketiga penjabaran tersebut antara lain (1) IPA sebagai produk, yaitu kumpulan hasil penelitian yang telah ilmuan lakukan dan sudah membentuk konsep yang telah dikaji sebagai kegiatan empiris dan kegiatan analistis. (2) IPA sebagai proses, yaitu menggali dan memahami pengetahuan tentang alam. Karena IPA merupakan kumpulan fakta dan konsep, maka IPA membutuhkan proses dalam menemukan fakta dan teori yang dapat digeneralisasikan oleh ilmuan. (3) IPA sebagai sikap, yang harus dikembangkan adalah sikap ilmiah dalam pembelajaran sains. Hal ini sesuai dengan sikap yang harus 
dimiliki oleh ilmuan dalam melakukan penelitian dan mengkomunikasikan hasil penelitiannya.

IPA juga memiliki karakteristik sebagai dasar untuk memahaminya. Karakteristik tersebut menurut Jacobson \& Bergman (dalam Susanto, 2016) yaitu: (1) IPA merupakan kumpulan konsep, prinsip, hukum, dan teori, (2) Proses ilmiah dapat berupa fisik dan mental, serta mencermati fenomena alam, termasuk juga penerapannya, (3) Sikap keteguhan hati, keingintahuan, dan ketekunan dalam menyingkap rahasia alam, (4) IPA tidak dapat membuktikan semua akan tetapi hanya sebagian atau beberapa saja, (5) Keberanian IPA bersifat subjektif dan bukan kebenaran yang bersifat objektif.

Adapun tujuan pembelajaran IPA di sekolah dasar dipaparkan oleh Badan Nasional Standar Pendidikan (Susanto, 2016) yaitu (1) Memperoleh keyakinan terhadap kebesaran Tuhan Yang Maha Esa berdasarkan keberadaan, keindahan, dan keteraturan alam ciptaanNya, (2) Mengembangkan pengetahuan dan pemahaman konsep-konsep IPA yang bermanfaat dan dapat diterapkan dalam kehidupan sehari-hari, (3) Mengembangkan rasa ingin tahu, sikap positif dan kesadaran tentang adanya hubungan yang saling mempengaruhi antara IPA, lingkungan, teknologi, dan masyarakat, (4) Mengembangkan keterampilan proses untuk menyelidiki alam sekitar, memecahkan masalah, dan membuat keputusan, (5) Meningkatkan kesadaran untuk berperan serta dalam memelihara, menjaga, dan melestarikan lingkungan alam, (6) Meningkatkan kesadaran untuk menghargai alam dan segala keturunannya sebagai salah satu ciptaan Tuhan. Berdasarkan pada penjelasan kompetensi pengetahuan dan hakikat IPA di atas, dapat disimpulkan bahwa kompetensi pengetahuan IPA adalah pemahaman untuk menggunakan perpaduan dari pengetahuan yang diperoleh dari pencapaian aspek kognitif melalui proses pembelajaran yang diberikan kepada siswa untuk mengembangkan potensinya guna mewujudkan tujuan dari dibelajarkannya IPA. CLIS adalah salah satu model pembelajaran inovatif yang tepat diterapkan dalam proses pembelajaran IPA. Rahayu (2015) menyatakan bahwa model pembelajaran CLIS merupakan model pembelajaran yang berusaha mengembangkan idea atau gagasan siswa tentang suatu masalah tertentu dalam pembelajaran serta merekonstruksi idea atau gagasan berdasarkan hasil pengamatan dan percobaan. Samatowa (2016:74) menyatakan bahwa "Model CLIS dikembangkan oleh kelompok Children's Learning in Science di Inggris yang dipimpin oleh Driver. Rangkaian fase pembelajaran pada model CLIS oleh Driver diberi nama general structure of a contructivism teaching sequence". Adapun Tujuan dari model pembelajaran CLIS untuk mengungkapkan gagasan serta membandingkan gagasan dengan gagasan siswa lainnya dan mendiskusikannya untuk menyamakan persepsi (Rahayu, 2015). Model pembelajaran CLIS memiliki karakteristik yaitu, (1) dilandasi oleh pandangan konstruktivisme karena membantu membangun pemikiran siswa, (2) pembelajaran berpusat pada siswa, (3) melakukan aktivitas hands on / mind on, (4) menggunakan lingkungan sebagai sumber belajar (Budiarti, 2014).

Berdasarkan pendapat tersebut, dapat disimpulkan bahwa model pembelajaran CLIS merupakan model pembelajaran yang melibatkan siswa secara aktif dalam berbagai aktivitas di dalam proses pembelajaran sehingga siswa dapat menggali pengetahuannya, menyusun gagasannya, mengkonstruksi gagasan baru, dan nantinya dapat menerapkan gagasannya tersebut berdasarkan hasil pengamatan dan percobaan.

Model pembelajaran CLIS memiliki beberapa langkah pembelajaran. Samatowa (2016) menyatakan bahwa ada lima tahap utama di dalam pembelajaran CLIS yaitu (1) Orientasi atau Orientation (2) Pemunculan Gagasan atau Elicitation Of Ideas (3) Penyusunan Ulang Gagasan atau Restructuring Of Ideas (4)Penerapan Gagasan atau Application Of Ideas (5) Pemantapan Gagasan atau Review Change Ideas. Suatu model pembelajaran yang dilaksanakan dalam proses pembelajaran pasti memiliki kelebihannya masing - masing , adapun kelebihan dari model pembelajaran CLIS menurut Lestari (2015) yaitu (1) Gagasan anak lebih mudah dimunculkan, (2) Membiasakan siswa untuk belajar mandiri dalam memecahkan suatu masalah, (3) Menciptakan kreatifitas siswa untuk belajar sehingga tercipta suasana kelas yang lebih nyaman dan kreatif, terjadi kerjasama sesama siswa dan siswa terlibat langsung dalam melakukan kegiatan, (4) Menciptakan belajar yang lebih 
bermakna karena timbulnya kebanggaan siswa menemukan sendiri konsep ilmiah yang dipelajari, (5) Guru mengajar lebih efektif karena dapat menciptakan suasana belajar yang aktif.

Pada proses pembelajaran media yang digunakan untuk memperlancar komunikasi antara siswa dan guru dinamakan media pembelajaran. Media pembelajaran merupakan sebuah alat bantu yang akan membantu kemudahan, kelancaran, serta keberhasilan proses belajar sebagaimana yang diharapkan (Susanto, 2014). Pembelajaran yang baik harus melihat keefektifan komunikasi anatara siswa dan guru yang terjadi dalam sebuah proses pembelajaran. Erviana (2015) menyatakan media adalah apa saja yang dapat menyalurkan informasi dari sumber informasi dari sumber informasi ke penerima informasi. Dapat disimpulkan bahwa media pembelajaran adalah segala sesuatu yang dapat digunakan sebagai sarana komunikasi di dalam sebuah proses pembelajaran untuk menyampaikan informasi sehingga pembelajaran dapat berlangsung secara efektif dan komunikatif. Salah satu media pembelajaran yang tidak dirancang itu adalah lingkungan. Samatowa (2016:103) menyatakan "Pembelajaran IImu Pengetahuan (IPA) di Sekolah Dasar (SD) dapat dilakukan di luar kelas (outdoor education) dengan memanfaatkan lingkungan sekolah sebagai sumber belajar". Berkaitan dengan upaya optimalisasi pemberdayaan masyarakat untuk pendidikan, maka pendayagunaan lingkungan hidup sangat relevan untuk mencapai tujuan pendidikan. "Lingkungan merupakan sumber belajar yang paling efektif dan efesien serta tidak membutuhkan biaya yang besar dalam meningkatkan motivasi peserta didik" (Uno dan Nurdin, 2017:137). Di dalam lingkungan menyediakan berbagai hal yang dapat menjadi bahan dalam sebuah pembelajaran. Lingkungan bisa dimanfaatkan oleh guru sebab sekolah telah bebas menentukan sumber belajar yang dibutuhkan siswa. Sebaiknya kita memperhatikan beberapa aspek yang dapat mensukseskan proses pembelajaran sebelum menggunakan lingkungan sebagai media pembelajaran. Lingkungan alam, sosial, dan budaya di sekitar sekolah merupakan sumber daya yang sangat kuat untuk bahan belajar siswa. Dapat menumbuhkan semangat dan motivasi siswa adalah salah satu manfaat lingkungan di sekolah dengan adanya pengaturan lingkungan kelas, karena dengan adanya pengaturan kelas yang baik akan memudahkan mewujudkan tujuan pembelajaran, misalnya bisa dirancang semenarik mungkin dengan gambar, warna, dan tulisan-tulisan yang memenuhi rasa etika dan konsep yang jelas. Selain penggunaan media lingkungan kelas, belajar diluar kelas dan memanfaatkan lingkungan sekitar akan mampu menggugah semangat belajar siswa dan menunjang tercapainya tujuan pembelajaran secara maksimal. Lingkungan sekolah sebagai laboratorium alam dapat didesain sebagai taman hias yang dijadikan sarana belajar (Samatowa, 2016). Hal ini akan mengefektifkan lingkungan sekolah serta membuat lingkungan kelas menjadi lebih indah dan asri.

Model pembelajaran CLIS berbantuan media lingkungan adalah model yang mengungkapkan berbagai gagasan tentang topic yang dibahas dalam pembelajaran, mengungkapkan gagasan serta membandingkan gagasan dengan gagasan siswa lainnya dan mendiskusikannya untuk menyamakan persepsi dengan mengaplikasikan kesatuan ruang dan keadaan makhluk hidup sebagai segala sesuatu yang dapat digunakan untuk menyampaikan pesan pada materi pembelajaran dalam pencapaian tujuan/ indikator yang telah ditentukan. Model pembelajaran CLIS berbantuan media lingkungan secara langsung mengajak siswa belajar sekaligus secara langsung mengajak siswa belajar memanfaatkan yang ada di sekitar lingkungan siswa.

\section{Metode}

Jenis penelitian yang dilakukan dalam penelitian ini adalah penelitian kuantitatif dengan desain eksperimen yaitu quasi eksperiment (Eksperimen Semu) dengan alasan tidak semua karakteristik dan kondisi eksperimen dapat diatur dan dikontol secara ketat seperti halnya dalam penelitian eksperimen murni (true experiment). Desain yang digunakan yaitu melibatkan dua kelompok kelas, yaitu kelompok kelas pertama sebagai kelas eksperimen yang mendapatkan perlakuan khusus dengan menggunakan model pembelajaran CLIS berbantuan media lingkungan dan kelompok kelas kedua sebagai kelas kontrol 
menggunakan pembelajaran konvensional. Rancangan eksperimen semu yang digunakan dalam penelitian ini adalah Nonequivalent Control Group Design.

\begin{tabular}{|ccc|}
\hline $\mathrm{O}_{1}$ & $\mathrm{X}$ & $\mathrm{O}_{2}$ \\
\hdashline $\mathrm{O}_{3}$ & & $\mathrm{O}_{4}$ \\
\hline
\end{tabular}

Gambar 1. Rancangan non-equivalent control group design

(Sumber : Sugiyono,2017:79)

Keterangan :

$\mathrm{O}_{1} \quad$ : Pre-test pada kelompok eksperimen

$\mathrm{O}_{2} \quad$ : Post-test pada kelompok eksperimen

$\mathrm{O}_{3} \quad$ : Pre-test pada kelompok kontrol

$\mathrm{O}_{4} \quad$ : Post-test pada kelompok kontrol

$\mathrm{X} \quad$ : Perlakuan pada kelompok eksperimen

Pre test diberikan untuk kelompok eksperimen dan kelompok kontrol. Setelah memberikan perlakuan, yaitu dengan memberikan model pembelajaran CLIS berbantuan media lingkungan kepada kelompok eksperimen sedangkan di kelas kontrol diberikan pembelajaran dengan pendekatan saintifik. Setelah diberikan perlakuan, data hasil kompetensi pengetahuan IPA diuji dengan membandingkan skor perolehan (gain score) antara pre test dan post test. Penelitian ini terdiri dari 3 tahapan yaitu tahap persiapan eksperimen, tahap pelaksanaan eksperimen, dan tahap akhir eksperimen.

Populasi pada penelitian ini adalah seluruh siswa Kelas IV SD Negeri Gugus Kolonel I Gusti Ngurah Rai Denpasar Utara Tahun Ajaran 2018/2019 yang berjumlah 464 siswa. Penentukan sampel menggunakan teknik sampling yaitu Simple Random Sampling. Teknik sampel ini dalam penarikan sampel menggunakan teknik random atau mengacak yang akan memberikan kesempatan kepada semua populasi untuk dapat diipilih menjadi sampel. Hasil pengundian diperoleh Kelas IVB SD Negeri 4 Ubung dan Kelas IVB SD Negeri 5 Ubung, selanjutnya diuji kesetaraannya dengan menggunakan uji-t yang terlebih dahulu data dari kedua kelompok sudah memenuhi uji prasyarat normalitas sebaran data dan mohogenitas varians.

Berdasarkan hasil uji-t yang dilakukan diperoleh bahwa kedua kelompok tersebut setara dengan hasil analisis menunjukkan nilai $t_{\text {hitung }}=0,972$, untuk $\mathrm{dk}=\left(\mathrm{n}_{1}+\mathrm{n}_{2}\right)-2=73$ dengan taraf signifikan $5 \%$ diperoleh $t_{\text {tabel }}=2,000$ sehingga $t_{\text {hitung }}<t_{\text {tabel }}$ maka $H_{0}$ diterima sehingga kedua kelompok setara. Selanjutnya diundi untuk menentukan kelompok kelas eksperimen dan kelompok kontrol, sehingga didapat Kelas IVA SD Negeri 4 Ubung sebagai kelompok kelas eksperimen dan Kelas IVB SD Negeri 5 Ubung sebagai kelompok kontrol.

Ada dua validitas terkait dengan penelitian yang dilakukan, yaitu validitas internal dan validitas eksternal. Validitas internal bersumber dari pelaksanaan penelitian itu sendiri, sedangkan validitas eksternal bersumber dari luar penelitian yang dilakukan.

Validitas internal dalam penelitian ini dapat berupa sejarah, kematangan, instrumentasi, regresi statistik, mortalitas dan seleksi kelompok. Keterbatasan yang ada berdasarkan sejarah dapat dikendalikan dengan cara menggunakan kelompok kontrol atau kendali yang dapat diharapkan memiliki pengalaman eksternal yang sama selama pelaksanaan perlakuan seperti pada kelompok eksperimen. Untuk mengatasi faktor kematangan peneliti melakukan penelitian dengan menggunakan kelompok kontrol yang memiliki kesamaan pengalaman kematangan. Faktor instrumentasi diatasi dengan memberikan tes yang sesuai dengan pelaksanaan perlakuan. Cara yang dapat digunakan untuk mengatasi regresi statistik yaitu dengan menghindari pemilihan subjek yang memiliki skor ekstrim dan tidak dilibatkan sebagai kelompok subjek penelitian. Menghindari adanya masalah yang diakibatkan oleh mortalitas eksperimental, maka perlu membuat kelompok yang lebih besar mengambil langkah-langkah untuk menjamin representatif kelompok, dan 
berupaya menindak lanjuti adanya ketidakseimbangan kelompok karena subjek yang mangkir atau tidak terlibat penuh dari perlakuan dan sebagainya. Cara yang dapat dilakukan untuk mengatasi seleksi kelompok yaitu dengan memberikan pre test kepada kedua kelompok yang menjadi sampel penelitian untuk menguji kesetaraan kelompok tersebut. Selain faktor internal, ada faktor lain yang bersifat eksternal yang memiliki pengaruh pada hasil penelitiannya yaitu validitas eksternal. Pengendalian terhadap ancaman tersebut dilakukan dengan membatasi penelitian pada kelas IV SD Negeri Gugus Kolonel I Gusti Ngurah Rai Denpasar Utara. Selain itu untuk mengendalikan ancaman ini juga dapat dilakukan dengan pemilihan anggota sampel secara acak untuk mewakili populasi.

Data yang dikumpulkan dalam penelitian ini adalah data kompetensi pengetahuan IPA siswa kelas IV SD Negeri Gugus Kolonel I Gusti Ngurah Rai Denpasar Utara 2018/2019. Menurut Setyosari (2015:247), "Prosedur pengumpulan data ini menuturkan bagaimana data penelitian itu diperoleh". Pada penelitian ini, metode pengumpulan data yang digunakan adalah metode tes. Tes adalah alat yang digunakan untuk mengukur pengetahuan atau pemahaman anak terhadap materi yang telah diberikan. Tes yang dipergunakan berupa tes objektif pilihan ganda biasa dan telah diuji validitas, daya pembeda, indeks kesukaran dan reliabilitas sehingga didapatkan 25 butir soal yang valid.

Data dalam penelitian ini dianalisis menggunakan statistik dan inferensial. Data yang dianalisis adalah data gain skor yang dinormalisasikan dari hasil pretest dan hasil posttest. Rumus untuk menghitung gain skor ternormalisasi adalah sebagai berikut.

$$
\text { GSn }=\frac{\text { Gain Skor }}{\text { Skor max-Skor pretest }}
$$

(Dantes, 2017:76)

Keterangan :

GSn = Gain Skor Ternormalisasi

GS $=$ Skor post test - Skor pre test

"Statistik deskriptif adalah statistik yang digunakan untuk menganalisis data dengan cara mendeskripsikan atau menggambarkan data yang telah terkumpul sebagaimana adanya tanpa bermaksud membuat kesimpulan yang berlaku untuk umum atau generalisasi" (Sugiyono, 2017:147). Teknik analisis dengan data kuantitatif dapat menggunakan teknik statistik deskriptif diantaranya menentukan nilai rerata (mean), simpangan baku, dan varians. Statistik inferensial adalah "teknik statistik yang digunakan untuk menganalisis data sampel dan hasilnya diberlakukan untuk populasi" (Sugiyono, 2017:148). Sebelum dilakukan uji hipotesis dengan statistik inferensial menggunakan statistik parametrik, data yang akan dianalisis harus mememnuhi beberapa prasyarat yaitu uji normalitas sebaran data dan uji homogenitas varians.

Uji Normalitas dilakukan untuk mengetahui apakah sebaran data kompetensi pengetahuan IPA siswa masing-masing kelompok berdistribusi normal atau tidak sehingga dapat menentukan teknik analisis datanya. Menghitung uji normalitas dalam penelitian ini menggunakan uji Kolmogorov-Smirnov. Kriteria pengujian adalah apabila nilai maksimum $\left|F_{T}-F_{S}\right| \leq$ nilai tabel Kolmogorov-Smirnov, maka data berdistribusi normal. Sebaliknya jika nilai maksimum $\left|\mathrm{F}_{\mathrm{T}}-\mathrm{F}_{\mathrm{S}}\right|>$ nilai tabel Kolmogorov-Smirnov, maka data tidak berdistribusi normal. Sedangkan untuk Uji homogenitas dilakukan untuk menunjukkan bahwa pengaruh yang terjadi pada uji hipotesis benar-benar terjadi akibat adanya pengaruh antar kelompok, bukan sebagai akibat pengaruh dalam kelompok. Uji homogenitas varians yang digunakan adalah uji Fisher $(F)$. Kriteria pengujian untuk mengetahui data yang mempunyai varians yang homogen yaitu, jika $F_{\text {hit }}<F_{\text {tabel }}$ maka sampel homogen. Pengujian dilakukan pada taraf signifikansi $5 \%$ dengan derajat kebebasan untuk pembilang $n_{1}-1$ dan derajat kebebasan untuk penyebut $\mathrm{n}_{2}-1$.

Data yang telah diuji normalitas dan homogenitasnya selanjutnya dilakukan uji hipotesisnya. Uji hipotesis yang dilakukan dalam penelitian ini menggunakan analisis uji-T dengan taraf signifikansi $5 \%$. Uji Hipotesis menggunakan uji-t dengan rumus polled varians. 
Rumus uji-t dengan rumus polled varians digunakan dengan jumlah anggota sampel sama $n_{1}$ $\neq \mathrm{n}_{2}$ dan varians homogen. Dengan kriteria jika harga $\mathrm{t}_{\text {hitung }} \leq \mathrm{t}_{\text {tabel }}$, maka $\mathrm{H}_{\mathrm{o}}$ diterima dan $\mathrm{H}_{\mathrm{a}}$ ditolak, dan jika harga $t_{\text {hitung }}>t_{\text {tabel }}$ maka $\mathrm{H}_{\mathrm{o}}$ ditolak dan $\mathrm{H}_{\mathrm{a}}$ diterima. Pada taraf signifikansi $5 \%$ dengan $\mathrm{dk}=\mathrm{n}_{1}+\mathrm{n}_{2}-2$.

\section{Hasil dan Pembahasan}

Objek pada penelitian ini adalah kompetensi pengetahuan IPA. Data yang dianalisis pada penelitian ini yaitu nilai gain skor dinormalisasi kompetensi pengetahuan IPA kelompok eksperimen dan nilai gain skor dinormalisasi kompetensi pengetahuan IPA kelompok kontrol. Mendeskripsikan data gain skor dinormalisasi kelompok eksperimen dilakukan dengan mencari Mean, Standar Deviasi, dan Varians dengan hasil sebagai berikut.

Tabel 1. Deskripsi data gain skor kelompok eksperimen

\begin{tabular}{cc}
\hline Mean & 0,596 \\
\hline Standar Deviasi & 0,180 \\
Varians & 0,032 \\
\hline
\end{tabular}

Selanjutnya distribusi frekuensi ganda kompetensi pengetahuan IPA siswa kelompok eksperimen dapat disajikan menggunakan grafik histogram sebagai berikut.

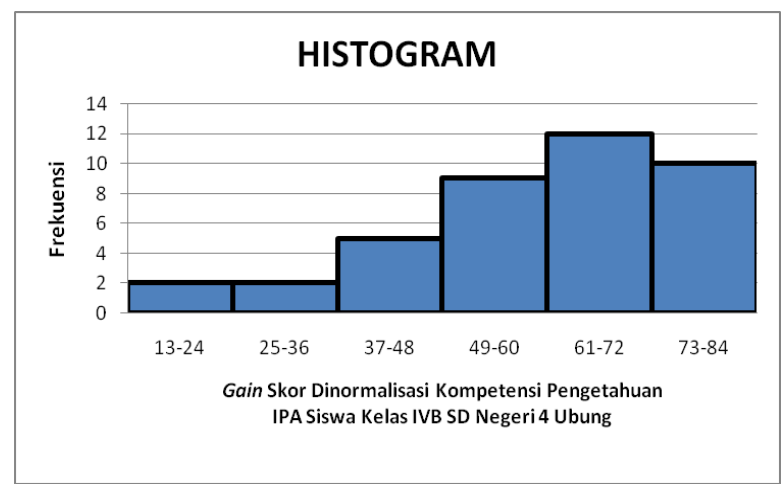

Gambar 2. Histogram gain skor dinormalisasi kompetensi pengetahuan IPA siswa kelompok eksperimen

Mendeskripsikan data gain skor dinormalisasi kelompok kontrol dengan mencari Mean, Standar Deviasi, dan Varians dengan hasil sebagai berikut.

Tabel 2. Deskripsi data gain skor kelompok kontrol

\begin{tabular}{cc}
\hline Mean & 0,486 \\
\hline Standar Deviasi & 0,191 \\
Varians & 0,037 \\
\hline
\end{tabular}

Selanjutnya distribusi frekuensi ganda kompetensi pengetahuan IPA siswa kelompok kontrol dapat disajikan menggunakan grafik histogram sebagai berikut. 


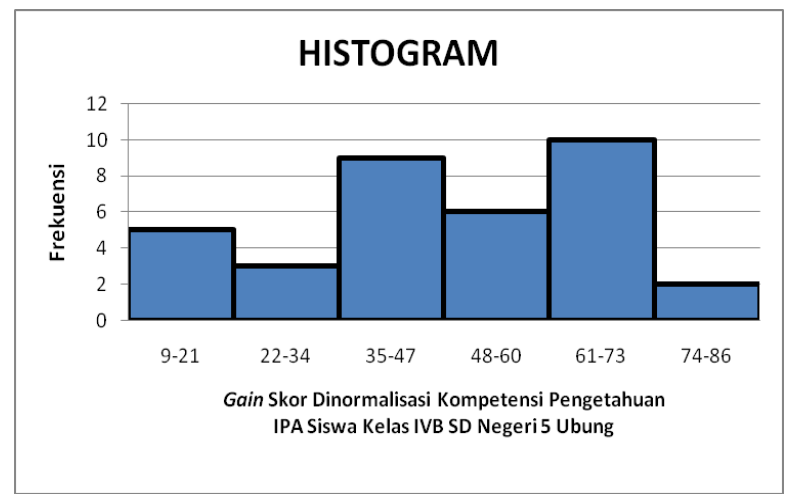

Gambar 3. Histogram gain skor dinormalisasi kompetensi pengetahuan IPA siswa kelompok control

Uji prasyarat dalam penelitian dilakukan sebagai syarat dipergunakanya statistik parametrik seperti penguji hipotesis dengan menggunakan uji-t. Uji prasyarat tersebut terdiri dari uji normalitas sebaran data dengan teknik kolmogorov-smirnov dan uji homogenitas varians dengan uji fisher $(\mathrm{F})$.

Berdasarkan hasil penghitungan tabel kerja uji normalitas sebaran data kelompok eksperimen diperoleh nilai $\left|\mathrm{F}_{\mathrm{T}}-\mathrm{Fs}\right|$ terbesar yaitu 0,101 . Nilai tersebut digunakan sebagai angka penguji normalitas sebaran data pada taraf signifikansi $5 \%$ untuk $n=40$ diperoleh nilai tabel kolmogorov-smirnov yaitu 0,215 sehingga perbandingan nilai $\mid \mathrm{F}_{\mathrm{T}}$-Fs $\mid$ terbesar $<$ nilai tabel kolmogorov-smirnov yaitu 0,101 <0,215, artinya sebaran data kelompok kelas eksperimen berdistribusi normal. Untuk kelas kontrol diperoleh nilai $\left|\mathrm{F}_{\mathrm{T}}-\mathrm{Fs}\right|$ terbesar yaitu 0,100 . Nilai tersebut digunakan sebagai angka penguji normalitas sebaran data pada taraf signifikansi $5 \%$ untuk $n=35$ diperoleh nilai tabel kolmogorov-smirnov yaitu 0,224 sehingga perbandingan nilai $\left|\mathrm{F}_{\mathrm{T}}-\mathrm{Fs}\right|$ terbesar < nilai tabel kolmogorov-smirnov yaitu 0,100<0,224, artinya sebaran data kelompok kontrol berdistribusi normal.

Uji homogenitas dapat dilakukan apabila data berdistribusi normal. Uji homogenitas dilakukan untuk menunjukkan bahwa perbedaan yang diperoleh uji-t benar-benar berasal dari perbedaan antar kelompok bukan disebabkan oleh perbedaan di dalam kelompok. Untuk menguji homogenitas variansi kedua kelompok digunakan uji $\mathrm{F}$. Dari hasil perhitungan diperoleh $F_{\text {hitung }}=1,15$. Sedangkan $F_{\text {tabel }}=1,68$. Pada taraf signifikansi $5 \%(\alpha=0,05)$ dengan derajat kebebasan pembilang $40-1=39$ dan derajat kebebasan penyebut $35-1=34$. Maka nilai $F_{\text {hitung }}=1,15<F_{\text {tabel }}=1,68$ yang disimpulkan bahwa data kedua kelompok memiliki variansi yang homogen.

Data yang telah memenuhi uji prasyarat analisis selanjutnya dilakukan uji hipotesis menggunakan analisis statistik parametrik dengan uji-t polled varians. Adapun hipotesis yang akan diuji pada penelitian ini yaitu tidak terdapat perbedaan yang signifikan kompetensi pengetahuan IPA antara kelompok siswa yang dibelajarkan menggunakan model pembelajaran CLIS berbantuan media lingkungan dan kelompok siswa yang dibelajarkan menggunakan pembelajaran konvensional siswa kelas IV SD Negeri Gugus Kolonel I Gusti Ngurah Rai Denpasar Utara 2018/2019.

Hasil perhitungan uji-t diperoleh $t_{\text {hitung }}=2,558$, sedangkan nilai $t_{\text {tabel }}$ pada taraf signifikansi $5 \%$ dengan $\mathrm{dk}=\mathrm{n}_{1}+\mathrm{n}_{2}-2=40+35-2=73$ menunjukkan nilai tabel sebesar 2,000. Sehingga diperoleh hasil analisis nilai $t_{\text {hitung }}=2,558>t_{\text {tabel }}=2,000$ maka $\mathrm{H}_{0}$ ditolak dan $\mathrm{H}_{\mathrm{a}}$ diterima. Hal ini menunjukkan terdapat perbedaan yang signifikan kompetensi pengetahuan IPA antara kelompok siswa yang dibelajarkan menggunakan model pembelajaran CLIS berbantuan media lingkungan dan kelompok siswa yang dibelajarkan menggunakan pembelajaran konvensional siswa kelas IV SD Negeri Gugus Kolonel I Gusti Ngurah Rai Denpasar Utara 2018/2019.

Perbedaan signifikan kompetensi pengetahuan IPA antara kelompok siswa yang dibelajarkan melalui model pembelajaran CLIS berbantuan media lingkungan dengan kelompok siswa dibelajarkan secara konvensional dapat dilihat dari perbedaan hasil analisis 
statistik deskriptif kedua kelompok tersebut. Secara deskriptif rata-rata gain skor dinormalisasi kompetensi pengetahuan IPA siswa kelompok eksperimen $\underline{X}_{a}=0,596$ dibandingkan dengan rata-rata gain skor dinormalisasi kompetensi pengetahuan IPA kelompok kontrol $X_{b}=0,486$. Jadi rata-rata gain skor dinormalisasi kompetensi pengetahuan IPA kelompok eksperimen $\underline{X}=0,596>\underline{X}=0,486$ kelompok kontrol dengan perbedaan sebesar 0,110. Sesuai hasil tersebut, dapat disimpulkan bahwa terdapat perbedaan signifikan kompetensi pengetahuan IPA antara kelompok siswa yang dibelajarkan melalui model pembelajaran CLIS berbantuan media lingkungan dengan kelompok siswa dibelajarkan secara konvensional pada kelas IV SD Negeri Gugus Kolonel I Gusti Ngurah Rai Denpasar Utara Tahun Ajaran 2018/2019.

Analisis statistik nilai pretest siswa diperoleh bahwa kedua kelompok kelas setara, setelah diberikan perlakukan berupa penerapan model pembelajaran CLIS berbantuan media lingkungan pada kelas eksperimen diperoleh perbedaan kompetensi pengetahuan IPA siswa. Nilai gain skor dinormalisasi kompetensi pengetahuan IPA siswa pada kelompok kelas eksperimen lebih tinggi dari gain skor dinormalisasi kompetensi pengetahuan IPA siswa pada kelompok kelas kontrol. Perbedaan tersebut terlihat dari rata-rata gain skor dinormalisasi kompetensi pengetahuan IPA siswa yang diberikan perlakuan model pembelajaran CLIS berbantuan media lingkungan lebih tinggi dibandingkan dengan rata-rata gain skor dinormalisasi kompetensi pengetahuan IPA siswa yang dibelajarkan secara konvensional. Pada kelompok eksperimen, kegiatan pembelajaran pada muatan materi IPA menerapkan model pembelajaran CLIS berbantuan media lingkungan berjalan dengan baik. Siswa menjadi lebih aktif dalam kegiatan pembelajaran, siswa menjadi lebih kreatif dan dapat menciptakan suasana belajar yang nyaman, dan juga terjadi kerjasama sesama siswa dan siswa terlibat langsung dalam melakukan kegiatan baik di luar kelas maupun di dalam kelas. Berbeda dengan pembelajaran yang dilaksanakan selama pembelajaran IPA di kelompok kontrol. Kegiatan pembelajaran hanya menggunakan pendekatan saintifik sehingga kurang berjalan dengan baik. Hal ini menyebabkan kurangnya keaktifan dan antusias siswa dalam proses pembelajaran. Kurang bervariasinya penggunaan media pembelajaran menyebabkan siswa cepat bosan dalam belajar serta pada kelompok control siswa cenderung bekerja sendiri dan tidak terdapat kekompakan, karena siswa tidak dibentuk dengan kelompok sehingga kurangnya kerjasama antar siswa.

Dengan demikian, perbedaan hasil kompetensi pengetahuan IPA siswa dapat terlihat dari keunggulan penerapan model pembelajaran CLIS berbantuan media lingkungan, nilai rata-rata gain skor dinormalisasi, dan hasil uji hipotesis dari kelompok kelas eksperimen dan kelompok kelas kontrol.

Hasil penelitian ini memiliki persamaan dengan penelitian sebelumnya yang relevan dan mendukung hasil penelitian relevan. Penelitian ini mendukung hasil penelitian yang dilakukan oleh Ambarwati (2016) dengan analisis menunjukkan bahwa terdapat perbedaan yang signifikan kompetensi pengetahuan IPS antara kelompok eksperimen dengan kelompok kontrol siswa kelas IV SD Gugus Mengwi Tahun Ajaran 2013/2014. Hal tersebut dibuktikan dengan $t_{\text {hitung }}=3,86>t_{\text {tabel }}=2,021$ dan diperoleh rata-rata skor siswa kelompok eksperimen $\bar{X}=23,33>\bar{X}=18,72$ siswa kelompok kontrol.

\section{Simpulan dan Saran}

Berdasarkan hasil penelitian dan pembahasan dari analisis data dapat disimpulkan bahwa nilai rata-rata gain skor kompetensi pengetahuan kelompok siswa yang dibelajarkan dengan model pembelajaran CLIS berbantuan media lingkungan yaitu 0,596 yang dikonversikan pada tabel PAN Skala 5 termasuk dalam kategori cukup baik. Untuk nilai ratarata gain skor kompetensi pengetahuan kelompok siswa yang dibelajarkan secara konvensional yaitu 0,486 yang dikonversikan pada tabel PAN Skala 5 tersamuk dalam kategori cukup baik.

Hasil analisis uji hipotesis menyatakan bahwa model pembelajaran CLIS berbantuan media lingkungan berpengaruh terhadap kompetensi pengetahuan IPA siswa kelas IV SD 
Negeri Gugus Kolonel I Gusti Ngurah Rai Denpasar Utara Tahun Ajaran 2018/2019. Hal ini dibuktikan dengan analisis uji-t diperoleh $t_{\text {hitung }}=2,558$ sedangkan pada taraf signifikan $5 \%$ dengan $\mathrm{dk}=73$ diperoleh nilai $\mathrm{t}_{\text {tabel }}=2,000$. Karena $\mathrm{t}_{\text {hitung }}=2,558>\mathrm{t}_{\text {tabel }}=2,000$, serta ratarata gain skor dinormalisasi kompetensi pengetahuan IPA kelompok kelas eksperimen $\underline{X}=$ $0,596>X=0,486$ rata-rata gain skor kompetensi pengetahuan IPA kelompok kelas kontrol.

Berdasarkan hasil penelitian ini, dapat diajukan beberapa saran sebagai tindak lanjut dari penelitian ini. Saran ini diajukan kepada berbagai pihak yang terkait dengan manfaat hasil penelitian.

Kepada guru disarankan lebih menambah wawasan dan pengetahuan tentang mengembangkan inovasi dan merancang pembelajaran untuk memberikan fasilitas berupa sumber belajar sertameningkatkan kualitas proses dan hasil pembelajaran dengan penerapan model pembelajaran CLIS berbantuan media lingkungan khususnya dalam pelajaran IPA dan mata pelajaran lain pada umumnya.

Kepada kepala sekolah disarankan untuk dapat menggunakan hasil penelitian ini sebagai pendukung sumber belajar guru dalam meningkatkan pembelajaran sehingga dapat meningkatkan mutu dan kualitas serta proses pembelajaran yang efektif dan efisien.

kepada peneliti lain disarankan untuk menggunakan hasil penelitian ini sebagai acuan dalam melakukan penelitian selanjutnya pada tema dan kegiatan pembelajaran lainnya untuk memperoleh hasil yang lebih baik.

\section{Daftar Pustaka}

Ambarwati, Kadek Nila. 2016. Pengaruh Model Children Learning In Science Terhadap Pemahaman Konsep IPA Siswa Kelas IV SD. Jurnal Mimbar PGSD Universitas Pendidikan Ganesha Volume 4, Nomor 1.

Budiarti, Luh Putu Yuda dkk. 2014. Pengaruh Model Pembelajaran CLIS Terhadap Hasil Belajar IPA Siswa Kelas IV SD di Gugus III Kecamatan Busungbiu. Jurnal Mimbar PGSD Universitas Pendidikan Ganesha, Volume 2 nomor 1.

Dantes, Nyoman. 2017. Desain Eksperimen dan Analisis Data. Depok: PT. Raja Grafindo Persada.

Erviana, Lina. 2015. Pemanfaatan Media Pembelajaran Berbasis Lingkungan Sebagai Sarana Praktikum IPA Untuk Meningkatkan Pemahaman Konsep Siswa di SMP-IT AR Rahmah Pacitan. Jurnal Dinamika Pendidikan Dasar, Volume 7 nomor 2.

Kurniasih, dan Sani. 2014. Sukses Mengimplementasikan Kurikulum 2014. Jakarta: Kata Pena.

Khusniati, M. 2014. Penerapan Critical Review Terhadap Buku Guru Ipa Kurikulum 2013 Untuk Mengembangkan Kemampuan Mahasiswa Dalam Menyusun Perangkat Pembelajaran Berpendekatan Saintifik . Jurnal Pendidikan IPA Indonesia JPII 3 (2) (2014)

Rahayu, Esti Setya. 2015. Aplikasi Model CLIS (Children's Learning In Sciense) Untuk Meningkatkan Kreativitas Belajar Kimia Siswa Kelas X MAN Tulungagung 1 Melalui Pembuatan Briket Sampah Organik. Jurnal Review Pendidikan Islam, Volume 1 nomor 2

Sanjaya, Wina. 2016. Strategi Pembelajaran Berorientasi Standar Proses Pendidikan. Jakarta: Prenadamedia Group.

Samatowa, Usman. 2016. Pembelajaran IPA di Sekolah Dasar. Cetakan Ke-tujuh. Jakarata: Indeks. 
Sani, Ridwan Abdullah. 2014. Pembelajaran Saintifik untuk Implementasi Kurikulum 2013. Jakarta: PT Bumi Aksara.

Sugiyono. 2017. Metode Penelitian Kuantitatif Kualitatif Dan R\&D. Bandung : Alfabeta.

Susanto, Ahmad. 2016. Teori Belajar Pembelajaran di Sekolah Dasar. Jakarta : Kencana Prenada Media Group.

Undang-undang Republik Indonesia Nomor 20 Tahun 2003 Tentang system Pendidikan Nasional

Uno, Hamzah B dan Nurdin Mohamad. 2017. Belajar dengan Pendekatan PAILKEM. Jakarta : Bumi Aksara

Wijayanti, Takdir Sukmo. 2014. Meningkatkan Minat Dan Prestasi Belajar Matematika Dengan Model Pembelajaran Group Investigation Siswa Kelas Vii A Smp Negeri 1 Polanharjo Klaten . Jurnal Pendidikan Matematika Vol 2 No 1, November 2014

Wisudawati, Asih Widi dan Eka Sulistyowati. 2015. Metodelogi Pembelajaran IPA. Jakarta : Bumi aksara

Yusuf, Muri. 2015. Asesmen dan Evaluasi Pendidikan. Jakarta: Prenadamedia Grup. 